Open Access

\title{
Scaffolding argumentative essay writing via reader-response approach: a case study
}

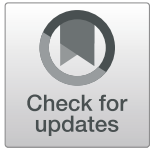

Mojgan Rashtchi(D)

\author{
Correspondence: mojgan.rashtchi@ \\ gmail.com; m_rashtchi@iau-tnb.ac.ir \\ TEFL Department, Faculty of \\ Foreign Languages, Islamic Azad \\ University, North Tehran Branch, \\ Hakimiyeh, Tehran, Iran
}

\begin{abstract}
The variety of activities and techniques suggested for improving the writing skill shows that EFL/ESL learners need scaffolding to gain mastery over it. The present study employed the reader-response approach to provide the assistance EFL learners require for writing argumentative essays. Five upper-intermediate EFL learners in a private class participated in the qualitative case study. The participants were not selected from the fields related to the English language and did not have any previous instruction on literary texts. During the treatment that took 20 sessions, each session $2 \mathrm{~h}$, the participants read five short stories. Different classroom activities were used as sources of information, which helped the researcher to collect the required data. The classroom activities consisted of group discussions, writing tasks, and responses to the short stories that helped the learners to reflect on the short stories. Think-aloud protocols helped the researcher to learn about the participants' mental processes during writing. The semi-structured interviews provided the researcher with the information necessary for a deeper understanding of the efficacy of the classroom procedure. As the results of the study showed, successful writing requires manipulation of meta-cognitive strategies and thought-provoking activities. Although the findings of the study cannot be generalized, they can inspire EFL/ESL teachers and material developers to seek a variety of procedures in their approaches to teaching writing.
\end{abstract}

Keywords: Argumentative essays, Literary texts, Reader response approach, Short stories, Thinking skills, Writing

\section{Introduction}

EFL/ESL learners encounter enormous challenges for mastering the writing skill, which is essential to learning the English language. One source of the problem is traceable to the learners' inefficiency in self-expression. Usually, language learners do not know how to verbalize their ideas, nor do they know how to organize their thoughts and write about a subject. In writing classes, learners not only should be instructed on the mechanics of writing, but also they should be taught how to use thinking skills. As Kellogg (1994) argues, "thinking and writing are twins of mental life" (p. 13), and writing requires tasks such as problem-solving, decision-making, and reasoning. Writing about what one knows, as Kellogg argues, is a self-discovery as much as it is one way of communication with others. However, excellence in writing requires excellence in thinking and requires systematic thinking (Paul, 1993). One should be able to arrange one's thoughts in a progression that makes it accessible to others.

(c) The Author(s). 2019 Open Access This article is distributed under the terms of the Creative Commons Attribution 4.0 International License (http://creativecommons.org/licenses/by/4.0/), which permits unrestricted use, distribution, and reproduction in any medium, provided you give appropriate credit to the original author(s) and the source, provide a link to the Creative Commons license, and indicate if changes were made. 
High-quality writing, then, is produced by someone with specific standards for both thinking and writing. As Lipman, Sharp, and Oscanyan (1980) assert, "if the thinking that goes on in a conversation is densely structured and textured, that which goes in the act of writing can be even more so" (p. 14). For successful writing, student-writers not only should express viewpoints but also they need to provide logical reasons, support their ideas, and organize them. Therefore, one requirement in teaching writing to EFL/ESL learners is to employ techniques and strategies that can enhance the thinking skills of the student-writers. The reader- response approach in the present study was implemented to do so.

Besides, one issue that Iranian EFL learners confront is the difference between the organizational patterns of English and Persian argumentative texts, which magnifies the challenge they encounter while writing. As found by Ahmad Khan Beigi and Ahmadi (2011, p. 177), Persian paragraphs are circular, metaphorical, and follow "Start-SustainTurn-Sum" structure, whereas English argumentative essays are straightforward and linear and follow "Claim-Justification-Conclusion or Introduction-Body-Conclusion" pattern. Also, contrary to English students who write "monotopical" essays, which add "unity to the overall paragraph organization", Iranian students tend to use more than one topic sentence and thus write multi-topical paragraphs as the result of the influence of different organizational patterns of English and Persian (Moradian, Adel, \& Tamri, 2014, p. 62; Rashtchi \& Mohammadi, 2017). Thus, reflection and response to literary texts were manipulated to help the EFL participants in the present study overcome the two-fold problem they might encounter in argumentative essay writing.

Using literature is by no means a novel idea in ESL/ EFL classes and has been extensively discussed by several scholars in the field (e.g., Gajdusek, 1988; Oster, 1989; Spack, 1985). The present study differs from the previous ones due to its underlying assumption that employing a scaffolded reader-response approach can change writing "from an intuitive, trial-and-error process to a dynamic, interactive and context-sensitive intellectual activity" (Hyland, 2009, p. 215). In this endeavor, reading short stories and creating personal interpretations could shape the participants' viewpoints, organize their thoughts, and help them produce compositions that conform to the English language structure.

\section{Literature review}

The role and use of literature in teaching writing have been a source of controversy in the studies related to the writing skill. Belcher and Hirvela (2000) in their comprehensive article about employing literature in L2 composition writing found the manipulation of literary texts in writing classes to be questionable, demanding further exploration despite all efforts to link writing and literature. One way to connect literature and writing is Rosenblatt's (1938) reader-response approach that Belcher and Hirvela refer to it as one way, which can reduce the problems of using literature in the classrooms. Spack (1985) also maintains that in writing classes reading literature encourages learners "to make inferences, to formulate their ideas, and to look closely at a text for evidence to support generalizations" which leads them to think critically (p. 721).

Furthermore, Shafer (2013, p. 39) maintains that if teachers decide to use literature in writing classes, "it should be approached in an inclusive, reader response method so that students have the opportunity to transact with the text and shape it." 
The reader response approach employs literary works in the English language classes and focuses on the reader rather than the text or as Rosenblatt (1976) conceptualizes, considers a creative role for the reader (p. 42). Therefore, it gives value to the reader as the driving force who can create meaning (Grossman, 2001) and provide new interpretations to a literary text. As Smagorinsky (2002) argues, in the reader-response approach, learners enrich the topic under scrutiny by their "previous experiences" and thus establish an "understanding of themselves, the literature and one another" (p.25). A critical characteristic of the reader-response approach is perspective-taking. According to Chi (1999), literary texts are not for teaching form and structure; preferably, they are a conduit of encouraging learners to read critically, to extract their understanding of a text, and as Rosenblatt (1985) maintains, to organize their thoughts and feelings when responding to them. The unique characteristic of the reader response approach, which values the readers' interpretations of a text due to emotions, concerns, life experiences, and knowledge they have can connect literature and writing.

A review of the related literature shows that the approach has been employed in English language classes to examine its effect on learners' understanding of literature as well as on developing linguistic and non-linguistic features. For example, Carlisle (2000) studied the effect of creating reading logs on the participants' reading a novel while Gonzalez and Courtland (2009) explored how by the manipulation of the readerresponse approach for reading a Spanish novel, the participants could learn the language, appreciate the cultural values, and improve their metacognitive reading strategies. Dhanapal (2010) reported that using reader-response could enhance the participants' critical and creative thinking skills. Also, Khatib (2011) used the approach for enhancing EFL learners' vocabulary knowledge and reading skills though she could not find a statistically significant difference between the experimental and control groups. In another study, Iskhak (2015) reported that the participants' personality characteristics and L2 speaking and writing improved as the result of participating in reading a novel and responding to it.

\section{The study}

The researcher was particularly interested in examining how the participants' mental processes after reading and reflecting on literary texts could help them in writing. She used group discussions and personal reflective writings as stimulators of thinking ability that seem to be responsible for creating good-quality essays. Thus, the reader-response was viewed as a starting point that could stimulate reflection, and if scaffolded by group discussions and writing tasks, it could enhance the elements of thinking necessary for providing argumentation in writing. Moreover, the classroom procedure was intended to help the participants adjust their essays to the rules (related to mono-topicality) of English writing. Multiple forms of data collection were employed for the present qualitative case study whose purpose was to describe a "phenomenon and conceptualize it" (Gall, Gall, \& Borg, 2003, p. 439).

Contrary to what is suggested by scholars regarding the occurrence of qualitative studies in natural settings (e.g., Creswell, 2013; Dornyei, 2007), this research was conducted in a classroom. The justification, according to Gall et al. (2003, p. 438), is that in occasions where "fieldwork is not done, the goal is to learn about the phenomenon 
from the perspective of those in the field." Thus, the following research questions were proposed to fulfill the objectives of the study:

RQ1: How does the reader-response approach operate in writing argumentative essays?

RQ2: How do the participants proceed with writing argumentative essays after reading short stories?

RQ3: How do the participants' essays before and after the treatment compare?

\section{Method}

Participants

Participants were five Iranian EFL learners who participated in a private writing class. Table 1 shows their demographic information. As the table shows, they had studied English for several years and had started learning English from childhood.

Meanwhile, all of them were attending language classes in different institutes in Tehran at the upper-intermediate level. However, they asserted that they needed individual instruction in the writing skill. The participants did not have any significant academic encounter with the English literature before the study.

\section{Teacher}

The teacher was the researcher of the study. Her B.A. degree in English language and literature, the literature courses she had passed as the requirements of her M.A. and Ph.D. in Applied Linguistics had provided her with a background in English literature. Additionally, teaching literature courses such as Oral Reproduction of Short Stories, Introduction to English Literature, and English Prose and Poetry in the university where she was a faculty member, had drenched her with the necessary knowledge to instruct the classes. Besides, teaching writing courses for more than 15 years, and publishing papers related to the writing skill gave her insight regarding teaching the skill.

\section{Data collection}

The researcher triangulated the study by different types of data obtained from several sources. First, an English proficiency test consisting of 20 vocabulary items, 30 structures, and three reading passages each followed by five comprehension questions extracted from TOEFL Test Preparation Kit (1995) was used to ensure the participants' homogeneity regarding the English proficiency level. The reason for using an old version of the test was to control the practice effect, as the participants were familiar with more recent versions.

Table 1 Participants' demographic information

\begin{tabular}{lllllll}
\hline Students & Male & Female & University Major & Age & Degree & Years of Studying English \\
\hline Azin & & $\checkmark$ & Computer Science & 23 & Master's Student & 13 years \\
Ali & $\checkmark$ & & Civil Engineering & 25 & Master's Degree & 18 years \\
Maryam & \multirow{2}{*}{$\begin{array}{l}\text { Mrchitecture } \\
\text { Melika }\end{array}$} & $\checkmark$ & Architecture & 25 & Master's Degree & 18 years \\
Nima & $\checkmark$ & & Mechanical Engineering & 23 & Master's Student & 17 years \\
\hline
\end{tabular}


Also, the participants were expected to write an essay on "Is capital punishment justified?" as both the pre and post writing tests in 250-300 words which could help the researcher have a clear understanding of their writing ability before and after the treatment. However, the researcher did not intend to go through any inferential statistics, as the study was a qualitative one.

To select a controversial topic of writing which could persuade the studentwriters to provide argumentations, the researcher prepared a list of ten topics and asked ten colleagues and ten students to mark the most challenging one. Thirteen of the respondents selected the topic related to capital punishment. Some of the other topics were, "Do we have the right to kill animals?" "Education must not be free for everyone," and "Internet access must be limited."

A writing rubric (Allen, 2009) was used for correcting the essays (Additional file 1). The rubric considers four levels (No/Limited Proficiency, Some Proficiency, Proficiency, High Proficiency) across five characteristics of originality, clarity, organization, support, and documentation. The participants' scores were obtained by adding the points for each level of writing, ranging from 1 for No/ Limited Proficiency to 4 for High Proficiency. The researcher and a colleague of hers who had also taught writing classes for about 10 years rated the essays. They negotiated on the merits and shortcomings of each essay and finally agreed on a quality mentioned in the rubric.

The next source of information was students' reflective responses written after reading the short stories. In these responses, the participants attempted to relate the stories to their personal experiences or write about their feelings, thoughts, and attitudes toward the stories.

Think-aloud protocols were also used as an instrument for data collection. Although according to Bowles (2010, p. 3), "requiring participants to think aloud while they perform a task may affect the task performance and therefore not be a true reflection of normal cognitive processing," its positive outcome cannot be denied. As Hyland (2009, p. 147) sustains, despite criticisms against think-aloud protocols, they are used extensively in different studies since "the alternative, deducing cognitive processes from observations of behaviour, is less reliable." Thus, the participants were trained on thinking aloud before the data collection, and then during the study, they were encouraged to report their thought processes while engaged in writing.

Another tool for data collection was a semi-structured interview conducted after completing the circle of reading each short story. The interviews were recorded and analyzed to enable the researcher to explore the participants' learning experience (Additional file 2).

\section{Materials}

The researcher selected five thought-provoking short stories of high literary merits to initiate class discussions and elicit responses from the participants. The stories were The Lottery (Jackson, 1948), The Rocking Horse Winner (Lawrence, 1926), The Storm (Malmar, 1944), The Last Leaf (Henry, 1907), and Clay (Joyce, 1914). 
Furthermore, the researcher prepared some tasks based on each story to help the participants practice writing and thinking skills (Additional file 3). Section A of the tasks required the respondents to organize the sentences according to the sequence of occurrence in the story. Section B asked the students to complete some incomplete sentences with "because," and Section C consisted of "WH" questions. Both sections required the learners to think and reason. The participants were expected to complete the threestep tasks after reading each story.

\section{Procedure}

The classes were held in fall 2018. The instruction took 20 sessions, each week, two sessions, and each session $2 \mathrm{~h}$. Before the advancement of the study, the researcher explained the classroom procedure and obtained the participants' consent regarding the teaching/learning procedure. Then they took the general proficiency and the writing tests to provide the researcher with an estimation of their English language level. In the three subsequent sessions, the researcher gave instructions on English essay writing and discussed the characteristics of an excellent essay. The samples of high-quality and weak essays presented during the instruction could elucidate the characteristics of argumentative essays. The first short story (The Lottery) was introduced in session four, which the learners were asked to read before the succeeding session.

In class, first, the researcher asked the participants to take turns and read the story aloud because as Gajdusek (1988) argues, "many clues to meaning are conveyed by intonation and other expressive devices available" (p. 238). Then some time was allocated to the reflection on the story that could lead to the intellectual involvement of the participants. In the next step, the class followed group discussions through which the learners struggled to verbalize their responses to the story. In this stage, the researcher encouraged talking about viewpoints and emotional states that the learners experienced after reading the story. Following Sumara (1995), the researcher took part in the discussions to show some of her understanding from the text, although she tried to be concise and give most of the discussion time to the learners. Through comments and questions, the researcher intended to encourage the participants to share ideas with classmates.

After the group discussion, which usually took about $45 \mathrm{~min}$, based on the readerresponse treatment, the learners wrote about their feelings and views without trying to stick to the rules of writing such as organization, punctuation, subject-verb agreement, and the like.

In the subsequent session, the researcher asked the student-writers to refer to their notes before doing the tasks. The tasks had a twofold purpose. First, they aimed to help learners organize their thoughts by reflecting on the story. Second, they enabled the learners to relate the stories to their personal experience and understanding. Once the participants completed the tasks, they were invited to agree about a topic more or less related to the theme of the story and start writing a five-paragraph essay. The researcher corrected the essays based on the writing rubric and returned them in the next session (Additional file 1). While the 
learners were involved in writing, each session, the researcher asked two or three of them to participate in the think-aloud process.

The third session was devoted to interviewing the learners. Each interview took about five to $10 \mathrm{~min}$. The participants started re-writing their essays based on the corrections after the researcher explained about their mistakes and errors. Table 2 summarizes the order of presenting the stories and topics attempted in the class.

Table 3 demonstrates the classroom procedure in each session.

\section{Results}

The researcher used the data derived from group discussions, reader-responses, thinkaloud protocols, and interviews to answer the first and second research questions. For answering the third research question, the quality of the essays written before and after the treatment was compared.

\section{Group discussions}

Before reading the first story, the participants were cynical regarding the usefulness of reading literature. They believed that the texts were too complicated; reading them was time-consuming and required skills different from the ones necessary for writing. However, after the first group discussion on The Lottery, they were excited. Some of the comments were:

"The discussions help us express the feelings and emotions [which were] there inside but couldn't find their way out," "Classes lower my anxiety," and "While reading, I felt I was in a different world forgetting [my problems]."

The discussions began with some challenging questions written by the researcher on the board. As the classes proceeded, the participants showed interest in the activity by listening to classmates, expressing viewpoints, and providing arguments. After reading the Lottery, Nima said:

Table 2 Short stories and writing topics

\begin{tabular}{|c|c|c|}
\hline \multicolumn{2}{|l|}{ Sessions } & \multirow{2}{*}{$\begin{array}{l}\text { Essay Topic } \\
\text { Is capital punishment } \\
\text { justified? }\end{array}$} \\
\hline 1 & $\begin{array}{l}\text { Explaining about the classroom procedure, Administering the English } \\
\text { proficiency test, and the pre-writing test }\end{array}$ & \\
\hline $2,3,4$ & Teaching characteristics of an essay, showing samples of good essays & \\
\hline $5,6,7$ & The Lottery & $\begin{array}{l}\text { The negative role of } \\
\text { traditions in our life }\end{array}$ \\
\hline $8,9,10$ & The Rocking Horse Winner & $\begin{array}{l}\text { In what ways can greed } \\
\text { destroy your life? }\end{array}$ \\
\hline $11,12,13$ & The Storm & $\begin{array}{l}\text { Building a better life needs } \\
\text { risk-taking }\end{array}$ \\
\hline $\begin{array}{l}14,15 \\
16\end{array}$ & The Last Leaf & $\begin{array}{l}\text { The role of motivation in } \\
\text { life }\end{array}$ \\
\hline $\begin{array}{l}17,18, \\
19\end{array}$ & Clay & $\begin{array}{l}\text { Superstitions should be } \\
\text { abandoned }\end{array}$ \\
\hline 20 & Writing Posttest & $\begin{array}{l}\text { Is capital punishment } \\
\text { justified? }\end{array}$ \\
\hline
\end{tabular}


Table 3 Classroom procedure in each cycle

\begin{tabular}{|c|c|c|c|c|}
\hline $\begin{array}{l}\text { Session } \\
\text { One }\end{array}$ & Reading Aloud & Reflecting & Group Discussion & $\begin{array}{l}\text { Writing } \\
\text { Responses }\end{array}$ \\
\hline $\begin{array}{l}\text { Session } \\
\text { Two }\end{array}$ & $\begin{array}{l}\text { Reading Personal } \\
\text { Responses (Silently) }\end{array}$ & $\begin{array}{l}\text { Doing } \\
\text { Tasks }\end{array}$ & Writing Essays \& Thinking Aloud (Volunteers) & \\
\hline $\begin{array}{l}\text { Session } \\
\text { Three }\end{array}$ & Participating in Interviews & $\begin{array}{l}\text { Re-writing } \\
\text { Essays }\end{array}$ & $\begin{array}{l}\text { Asking Questions (if any) from the Teacher } \\
\text { About Her Corrections }\end{array}$ & \\
\hline
\end{tabular}

"I was shocked when I read the story, the name of the story implies something good, but something awful happened ... how amazing!"

Maryam added:

"It's like life when you expect good things and bad things happen."

Azin looked at the story from a different perspective:

"How selfish people can be, exactly like what happens nowadays, we keep silence until something injures [us].”

And Melika believed:

"Others' miseries are a relief for us ... how cruel human beings can be, and this is true even in today's civilized world."

When reading Clay, Nima said:

"I was expecting something unusual to happen, something which needs thinking and interpreting, I was sure clay implied something...not expecting."

Ali asserted that he could understand literature better, could go beyond words, think more profound, and analyze the events in the short stories. The group discussions showed that the participants connected themselves with the stories and characters, and although they were unfamiliar with the English literature, they started appreciating the literary values of the stories.

Another advantage of the classes was the mental relief they caused as reflected in Melika's words:

"It is interesting to read about people who do not worry about the messages on their cell phones!"

One crucial point in the class discussions was the improvement of vocabulary knowledge. The participants sought to use words and phrases they had encountered in the stories. They asserted that reading and discussing literary texts helped them remember words with more ease. Besides, the discussions gave them self-confidence in selfexpression and overflow of feelings. Maryam emphasized the role of group discussions in shaping her thoughts: 
"They [group discussions] were constructive; made me think and get familiar with others' views ... sometimes you think there is only one way of looking at something ... then you find out ... issues which you had never thought about before."

Sharing ideas gave learners the courage to reason, evaluate, justify, agree, and disagree. Expressing agreement and disagreement regarding an issue was an achievement for the learners because it helped them while writing essays.

Another advantage of the group discussions was that they enhanced attention to the details. As the classes proceeded, the participants were conscious of the details mentioned in the stories, and tried to relate them to the plot and characters of the story and tried to infer the meaning they implied. For example, Maryam said:

"The storm has a double meaning; it refers both to the weather and her inner feelings."

Melika mentioned:

"Drooped shoulders show how anxious she was."

Azin referred to a sentence from the story (But now, alone and with the storm trying to batter its way in, she found it frightening to be so far away from other people) and stated:

"The storm inside her was destroying the image she had built of her life...now she was trying to find someone to stick ... watching the imaginary heaven breaking ... into pieces."

The following excerpt is an example from group discussions on Clay to show how the class progressed in answering the leading question: "How do you feel about Maria?"

Azin: I think she is an unmarried middle-aged woman ... I sympathize with her.

Maryam: Why? ... ... .. why sympathize?

Azin: Because she is not married.

Maryam: Is not being married a reason for sympathizing with someone?

Melika: No, not marriage ... ... but loneliness ... .. she was very lonely.

Ali: Melika is right. Loneliness is too bothering, especially for the old; old age brings worries for people. I always try to show my concern for the elderly.

Nima: Good thing to do. But I think some sort of sadness was around her which made me very sad, too...the writer implied kind of nothingness ... ... after so many years working she had nothing to be happy for.

Azin: I do not agree, why nothingness ... such is life, 1 day we come [to this world], and 1 day we must go ... . this tells us to enjoy life. 
Maryam: Azin is right. Life is a blessing; we should enjoy every minute of it.

Teacher: Let's try to conclude. Nima ... .please, the keywords were loneliness, sadness, marriage, life, and happiness.

\section{Reader-responses}

The responses promoted the participants' focus on the stories. They pointed toward their inner feelings, judgments, preferences, and thoughts about the themes of the stories. They had addressed themselves and the characters and had put themselves in their place. They had used both questions and statements in the responses. Two responses to the Rocking Horse Winner by Maryam and Azin are as follows:

"She had bonny children, yet she felt they had been thrust upon her, and she could not love them." There are hundreds of people who can't have children, you are lucky...Sometimes ... we cannot realize how lucky we are, I am most [ly] like that ... I should not be!"

" ... they had discreet servants, and felt themselves superior to anyone in the neighbourhood." Feeling you are superior can destroy you ... this is what kills human beings. When you think it is your right to have everything and ... you forget others ... sometimes others deserve but don't have as much as you."

Overall, the responses facilitated remembering the sequence of events in the stories. The tasks, together with group discussions, helped the participants organize their thoughts, and thus avoid recursive or cyclical writing. For example, on the first topic, "The negative role of traditions in our life," Melika wrote:

"Traditions can have both positive and negative roles in our lives. The negative role of traditions is most of the time more dominant though positive roles can be mentioned, as well. The negative role of traditions can cause ignorance, unawareness, and cruelty. Traditions can change the direction of people's lives and force them to choose ways that are not appropriate. However, traditions can bring about good things, too."

The writing is recursive as it repeats the idea of negative and positive aspects continuously. However, comparing Melika's first writing with the last one, "Superstitions should be abandoned," shows her improvement in expressing her idea clearly:

Superstitions are the result of [a] human being's ignorance. People resort to them when they cannot find solutions to their problems or are not strong enough to face the disasters they encounter.

Additionally, the tasks enhanced reasoning and looking for evidence among the learners. For instance, Ali's writing on the first topic not only shows his tendency to repeat the same idea but also reveals his lack of reasoning and thus relying on "educated people" and "scholars" to prove himself: 
"Educated people never show a tendency toward traditions. Scholars believe that traditions are not scientific, and in today's world, we must pay attention to scientific findings to solve our problems. The scientific developments help us to be able to live in this modern world."

However, his introductory paragraph on "the role of motivation in life" showed some argumentation in developing his writing:

"Motivation seems to have a positive role in our life and can help us to do different activities with less effort and more energy. For example, when we are interested in completing a project, we do not feel tired, but we think about the sense of achievement we will gain."

\section{Think-aloud protocols}

As stated above, think-aloud protocols mainly focused on the participants' thinking processes while they were engaged in writing. In each writing session, two or three learners participated in the think-aloud procedure. The researcher sat beside one of the participants who had agreed to take part in the thinking protocol. S/he explained the strategies s/he was using or accounted for his/her thought processes. All participants' voices were recorded by their permission and transcribed for further analysis.

The analyses of the protocols showed that all participants first tried to take a perspective regarding the topic of the writing. The most frequent strategy was self-questioning. They first wrote questions and then answered them. Some questions were, "What do I think about the topic? Why do I think so? What are my reasons? What is the evidence to support my idea? Are my reasons logical?" Moreover, they reported that they used mind maps and outlines before beginning to write. Another strategy was using the phrases and words they had extracted and memorized from the texts that, as they asserted, could help them start writing.

Developing an inner dialogue before writing was another strategy used by the participants. Maryam said:

"I ... talk to myself and meanwhile try to write all of the sentences I exchange with myself during the dialogue. Then I organize them."

Translating from L1, trying to write for an audience and drafting were other strategies used by the participants.

An interesting point mentioned by Maryam, Ali, and Nima was thinking about the stories before writing:

"... in this way, writing becomes easier."

"Discovering what you really think about a subject is difficult ... I cannot make a decision ... but the story is really helpful ... it gives direction to my thoughts."

"I don't know how to start my essay, that is why I am trying to review the story in my mind ... ." 


\section{Interviews}

During the interviews, the participants talked about their learning experience. Their answers to the first interview question showed that they viewed writing a troublesome and challenging activity that needed expertise beyond general proficiency in English. They believed that for effective writing, besides knowledge of the language, learners should learn how to organize their thought processes and transfer them to words. They believed that the classroom procedure gave direction to their thoughts and enabled them to think and write systematically. Some of the advantages of reading literature, as they mentioned, are as follows:

"The use of technology makes me tired; people are always checking something in their cell phones; human relations are weakening ... I think reading and sharing ideas is a relief."

"Freeing myself from my problems was great ... reading stories gave me something different from the routines of life."

"The class gave me a reason to talk ... something I miss nowadays ... I am fed up with reading and writing in the [social network]."

"I hate traditional classes they do not give me space to be myself and talk about something different from casual things."

“... it was the first time I enjoyed writing because I had ideas to write about. I could [let] myself go."

Regarding the second question, the learners believed that perspective-taking and organizing ideas were the most demanding tasks while they also maintained that controlling both content and form was difficult. Melika stated:"if it were not for grammar, I would have been more comfortable to express myself."

Moreover, three of the participants (Maryam, Ali, and Nima) pointed to group discussions and mentioned that in the very first sessions, it was difficult for them to express their viewpoints regarding the topic of the discussions, but as the classes continued, they gained the necessary self-confidence. Maryam stated:"As the classes started, I was [worried] about my ideas to be irrelevant ... I could have seemed funny ... but little by little I gained courage to speak out."

The flow of ideas was considered the most encouraging characteristic of the class (third interview question) for all of the participants. They believed that the short stories were excellent sources of ideas, and responding to them stimulated looking at the themes of the stories from a different perspective. Additionally, listening to classmates was considered encouraging because their opinions inspired confidence, thinking, and appreciation for literature.

Regarding the fourth interview question, the learners pointed to the role of the reader-response approach in boosting thinking skills, shaping ideas, and recovering life experiences. Further, all participants asserted that the approach could enhance 
inferencing, logical reasoning, and analyzing. They underlined the deep thinking brought about by transferring knowledge from the short stories to their personal lives and believed that by reading and reflecting on the stories, they realized that they had never had the opportunity to think deeply about some of the themes entailed in the stories. Subjects such as greed, selfishness, truth, security, and superstition were the subjects, which triggered thinking and led to a better understanding of human nature, the value of life, and social relations. They underscored the role of the classroom procedure in shaping their ideas and providing them with the input they required for writing.

\section{Writing pretest and posttest}

The comparison between the pretest and posttest seemed to be worthy of note. As Table 4 shows, the participants' writings show a change of status from the pretest to the posttest in the components of the rubric. For example, regarding Originality, the raters witnessed a shift from "Limited Proficiency" in the pretest to "Proficiency" (Azin, Ali, Melika) and from Some Proficiency to "High Proficiency" (Maryam, Nima) in the posttest. Azin wrote the following sentence as the thesis of her essay:

"Capital punishment is a death penalty for wrongdoing."

While in the posttest, she wrote:"Crimes are the result of the pressure society puts on individuals' minds and souls."

Maryam's thesis statement in the pretest was:"Human beings do not have the right to kill people [for] committing crimes."

Table 4 The evaluation of the participants' writings

\begin{tabular}{|c|c|c|c|c|c|}
\hline & Originality & Clarity & Organization & Support & Documentation \\
\hline \multicolumn{6}{|l|}{ Prewriting } \\
\hline Azin & $\begin{array}{l}\text { Limited } \\
\text { Proficiency }\end{array}$ & $\begin{array}{l}\text { Some } \\
\text { Proficiency }\end{array}$ & $\begin{array}{l}\text { Limited } \\
\text { Proficiency }\end{array}$ & $\begin{array}{l}\text { Limited } \\
\text { Proficiency }\end{array}$ & $\begin{array}{l}\text { Limited } \\
\text { Proficiency }\end{array}$ \\
\hline Ali & $\begin{array}{l}\text { Limited } \\
\text { Proficiency }\end{array}$ & $\begin{array}{l}\text { Some } \\
\text { Proficiency }\end{array}$ & $\begin{array}{l}\text { Limited } \\
\text { Proficiency }\end{array}$ & $\begin{array}{l}\text { Limited } \\
\text { Proficiency }\end{array}$ & $\begin{array}{l}\text { Limited } \\
\text { Proficiency }\end{array}$ \\
\hline Maryam & Some Proficiency & $\begin{array}{l}\text { Some } \\
\text { Proficiency }\end{array}$ & $\begin{array}{l}\text { Limited } \\
\text { Proficiency }\end{array}$ & $\begin{array}{l}\text { Limited } \\
\text { Proficiency }\end{array}$ & $\begin{array}{l}\text { Limited } \\
\text { Proficiency }\end{array}$ \\
\hline Melika & $\begin{array}{l}\text { Limited } \\
\text { Proficiency }\end{array}$ & $\begin{array}{l}\text { Some } \\
\text { Proficiency }\end{array}$ & $\begin{array}{l}\text { Limited } \\
\text { Proficiency }\end{array}$ & $\begin{array}{l}\text { Limited } \\
\text { Proficiency }\end{array}$ & $\begin{array}{l}\text { Limited } \\
\text { Proficiency }\end{array}$ \\
\hline Nima & Some Proficiency & $\begin{array}{l}\text { Some } \\
\text { Proficiency }\end{array}$ & $\begin{array}{l}\text { Limited } \\
\text { Proficiency }\end{array}$ & $\begin{array}{l}\text { Limited } \\
\text { Proficiency }\end{array}$ & $\begin{array}{l}\text { Limited } \\
\text { Proficiency }\end{array}$ \\
\hline \multicolumn{6}{|c|}{ Post Writing } \\
\hline Azin & Some Proficiency & Proficiency & High Proficiency & Proficiency & Some Proficiency \\
\hline Ali & Some Proficiency & High Proficiency & High Proficiency & Proficiency & Some Proficiency \\
\hline Maryam & High Proficiency & High Proficiency & High Proficiency & Proficiency & Some Proficiency \\
\hline Melika & Some Proficiency & $\begin{array}{l}\text { Some } \\
\text { Proficiency }\end{array}$ & Proficiency & Proficiency & Some Proficiency \\
\hline Nima & High Proficiency & High Proficiency & High Proficiency & Proficiency & Some Proficiency \\
\hline
\end{tabular}


While in the posttest, she wrote:"Crimes are the manifestation of [the] society's failure in evaluating humanity among its members, and the death penalty is the reflection of the deficiency of social institutions."

Regarding Clarity, the second criterion in the writing rubric, all participants' writing showed a shift from "Some Proficiency" to "Proficiency" (Azin, Melika) and to "High Proficiency" (Ali, Maryam, Nima). Ali's improvement can be shown in the following examples extracted from the pretest and posttest, respectively:

"Due to the fact that crime is the child of society, it can be studied from different perspectives. Of course, this is relative."

"Crimes are the result of social injustice, and factors such as poverty, unemployment, and lack of enough education are responsible for leading people toward committing crimes. However, the question is whether the death penalty is the only solution against criminals."

However, considering the fifth criterion, the Use of Sources/Documentation, the participants did not show much improvement. Their writings showed a shift from "No/ Limited Proficiency" to "Some Proficiency" which could be due to the lack of enough time, not having access to different sources while writing, and not having enough practice in using references and quotations from other sources.

Table 5 presents the participants' scores obtained from the proficiency test and the writing pretest and posttest. The writing scores signify improvement. It is worth mentioning that although the present study was a qualitative one, quantification was used for clarification since "numerical descriptions can make it readily apparent ... why researchers have drawn particular inferences" (Mackey \& Gass, 2005, p. 182).

\section{Discussion}

The data gathered from the diverse sources were employed to answer the first research question of the study. Group discussions were useful in helping the participants listen to others and get acquainted with their viewpoints. Listening to classmates exposed learners to a plethora of ideas, helped them avoid biases (Lipman, 2003), and enabled them to provide arguments and counterarguments. Reading short stories facilitated writing as they took the role of brainstorming before writing activity and gave direction to the learners' thoughts (Spack, 1985).

Table 5 Participants' scores on tests

\begin{tabular}{llll}
\hline Learners & English Proficiency Test Scores & $\begin{array}{l}\text { Prewriting Test } \\
\text { Max. 20 }\end{array}$ & $\begin{array}{l}\text { Post Writing Test } \\
\text { Max. 20 }\end{array}$ \\
\hline Azin & 55 & 6 & 15 \\
Ali & 57 & 6 & 16 \\
Maryam & 61 & 7 & 17 \\
Melika & 54 & 6 & 14 \\
Nima & 60 & 7 & 17 \\
\hline
\end{tabular}


The reader-response approach, accompanied by other classroom activities provided appropriate mental exercises that could activate the participants' thinking skill. In line with Paul (1993), this study implies that thinking is a potential that needs to flourish through appropriate mental exercises. The reader-response approach can encourage learners to reflect on what they read and to decide on their perspective. The integration of reading literary texts and reflecting on them enhance focus on the sequence of events, promote inferencing, and thus, as Rosenblatt (1976) argues, help learners, become agents who give meaning to the text they read.

Moreover, the reader-responses could help learners become "conscious of the reasons and evidence that support this or that conclusion" (Lipman, 2003). In line with Kellogg (1994), this study supports the idea that writing and thinking are intertwined skills and improving writing skills is connected to fostering the thinking ability of learners. In the same vein, Oster (1989, p. 100) also connects literature, critical thinking, and writing as she asserts that when students engage in discussing what they have read, they "develop the capacity to see" things with more precision and intensify their "seeing" by writing.

The think-aloud protocols and answers to the interview questions showed that the participants enjoyed reading the literary texts and believed that the texts could shape their awareness toward the details that they commonly fail to attend while encountering different issues in the real-life. Moreover, they successfully related the themes of the stories with their personal experiences, which could facilitate their perception and recall (Sherman, 2013).

Likewise, the data gathered from the think-aloud protocols and interviews enabled the researcher to answer the second research question of the study. The analysis of the learners' answers revealed that connecting writing and literature could turn writing to a meaningful task which prevents the student-writers from becoming "passive recipients of teacher-driven models and assignments" (Shafer, 2013). The participants' use of metacognitive strategies (e.g., self-questioning, outlining), which was stimulated by the writing activity after reading short stories shows that personal interpretations and reflection can activate the cognitive structure of student-writers. Furthermore, the emergence of inner-dialogues after reading activity shows that short stories could cultivate reflection, analysis, and inferencing.

The comparison of the students' writing before and after the manipulation of the reader-response approach was employed to answer the third research question. As the writings signified, the learning process implemented in the study was successful in improving the participants' writings regarding originality, clarity, organization, and reasoning.

As stated in the introduction section, one problem with Iranian EFL learners' writings is "multi-topicality and the use of different forms of parallelism" (Ahmad Khan Beigi \& Ahmadi, 2011; Moradian et al., 2014; Rashtchi \& Mohammadi, 2017) which originates from their thinking structure and their first language. The planned classroom procedure employed in this study could improve learners' writings because it was a practice for organized and linear thinking. This account finds support from Wegerif (2006, p.17) who believed that the teaching of thinking skills "needs to be carefully contextualized to be effective." The study suggests that thinking skills, triggered by the readerresponse approach, can be transferred to the writing skill. In line with Rashtchi (2007) 
and Topping (2001), the present study states that one way of teaching thinking skills is through another transferable skill such as reading and writing.

\section{Conclusions}

Written tasks and group discussions scaffold the reader-response approach and lead to productive outcomes in thinking and writing. This study suggests that reflection and response cannot turn into writing skill automatically. The various data gathering tools clarified that the reader-response is a thought-provoking activity and can stimulate the employment of thinking strategies. The classroom procedure adopted in this study was a carefully designed activity to improve learners' writing by tapping their thinking skills.

The present study was a small-scale study, which aimed to probe its participants' mental processes and report how they reacted toward reading literature, reflecting, and writing. The aim of this study was not to generalize findings but to encourage teachers to employ a variety of techniques and procedures to help their students improve their language skills.

\section{Supplementary information}

Supplementary information accompanies this paper at https://doi.org/10.1186/s40862-019-0078-2.

Additional file 1. Writing Rubric. Northeastern Illinois University (Adapted from B. Walvoord by Allen, 2009).

Additional file 2. Interview Questions.

Additional file 3. Sample Task. The Lottery (Shortened to meet word limits).

\section{Acknowledgments}

I am indebted to the participants who voluntarily took part in this study and who kindly consented to cooperate in the data collection procedure, including think-aloud and interview sessions. Following their request, although I cannot mention their full names, I do appreciate what they did to make this study possible.

\section{Authors' contributions}

This study is a single-author study, and the only contributor is the author herself. The author read and approved the final manuscript.

\section{Funding}

No funding was received for this study.

Availability of data and materials

The data and materials will be available upon request.

Competing interests

The author declares that she has no competing interests.

Received: 19 June 2019 Accepted: 30 October 2019

Published online: 27 November 2019

\section{References}

Ahmad Khan Beigi, S., \& Ahmadi, H. (2011). Rhetorical patterns of structural and rhetorical patterns of Persian and English argumentative essays. The Iranian EFL Journal, 7(1), 167-178.

Allen, M. (2009). Developing and using rubrics for assessing, grading, improving student writing. [Adapted from Barbara Walvoord, Winthrop University, University of Washington]. www2.humboldt.edu/../Complete\%20Writing\%20Rubric\%2 OPacket\%20by\%20Mary...Mary Allen. Accessed 12 June 2016.

Belcher, D., \& Hirvela, A. (2000). Literature and L2 composition: Revisiting the debate. Journal of Second Language Writing, 9(1), $21-39$.

Bowles, M. A. (2010). The think-aloud controversy in second language research. New York: Routledge.

Carlisle, A. (2000). Reading logs: An application for reader-response theory in ELT. ELT Journal, 54(1), 12-19. https://doi.org/10. 1093/elt/54.1.12.

Chi, F. M. (1999). Reading as a transaction in EFL: A thematic analysis. National Chung Cheng University https://files.eric.ed.gov/ fulltext/ED437855.pdf. Accessed 25 Dec 2018.

Creswell, J. W. (2013). Qualitative inquiry and research design. Thousand Oaks: Sage.

Dhanapal, S. (2010). Stylistics and reader response: An integrated approach to the teaching of literary texts. Literacy Information and Computer Education Journal (LICEJ), 1(4), 233-239.

Dornyei, Z. (2007). Research methods in applied linguistics. Oxford: Oxford University Press. 
Gajdusek, L. (1988). Toward wider use of literature in ESL: Why and how. TESOL Quarterly, 22(2), 227-257. https://doi.org/10. 2307/3586935.

Gall, M. D., Gall, J. P., \& Borg, W. R. (2003). Educational research (7th ed.). Boston: Pearson.

Gonzalez, I., \& Courtland, M. C. (2009). Reader response as a focal practice in modern language acquisition. Journal of the Canadian Association for Curriculum Studies, 7(2), 110-138.

Grossman, P. L. (2001). Research on the teaching of literature: Finding a place. In V. Richardson (Ed.), Handbook of research on teaching (4th ed., pp. 416-432). Washington, D.C: American Educational Research Association.

O. Henry. (1907). The last leaf. http://americanenglish.state.gov/files/ae/resource_files/the-last-leaf.pdf. Accessed 27 May 2018.

Hyland, K. (2009). Teaching and researching writing (2nd ed.). Edinburgh: Pearson.

Iskhak, I. (2015). The application of reader-response theory in enhancing student teachers' affective and linguistic growth: A classroom action research in EFL teacher education in Indonesia. The English Teacher, XLIV(2), 43-55.

Jackson, S. (1948). The lottery. https://sites.middlebury.edu/individualandthesociety/files/2010/09/jackson_lottery.pdf. Accessed 25 May 2018

Joyce, J. (1914). Clay. http://www.classicshorts.com/stories/clay.html. Accessed 25 May 2018.

Kellogg, R. T. (1994). The psychology of writing. New York: Oxford University Press.

Khatib, S. (2011). Applying the reader-response approach in teaching English short stories to EFL students. Journal of Language Teaching and Research, 2(1), 151-159.

Lawrence, D. H. (1926). The rocking horse winner. http://blogs.bu.edu/cflamm/files/2012/10/The-Rocking-Horse-Winner.pdf. Accessed 25 May 2018.

Lipman, M. (2003). Thinking in education. New York: Cambridge University Press.

Lipman, M., Sharp, A. M., \& Oscanyan, F. S. (1980). Philosophy in the classroom (2nd ed.). Philadelphia: Temple University Press.

Mackey, A., \& Gass, S. M. (2005). Second language research. Mahwah: Lawrence Erlbaum.

Malmar, M.K. (1944). The storm. https://www.scasd.org/cms/lib/PA01000006/Centricity/Domain/1487/McKNIGHT\%2 OMALMAR\%20Storm.pdf. Accessed 25 May 2018.

Moradian, M. R., Adel, S. M., \& Tamri, M. S. (2014). An intercultural rhetoric investigation of the discourse topic in the English and Persian editorials. Switzerland Research Park Journal, 103(1), 62-72.

Oster, J. (1989). Seeing with different eyes: Another view of literature in the ESL class. TESOL Quarterly, 23, 85-103. https://doi. org/10.2307/3587509.

Paul, R. W. (1993). Critical thinking. San Francisco: Foundation for Critical Thinking.

Rashtchi, M. (2007). A pathway toward critical thinking through cooperative writing in an English college course in Iran. The Near and Middle Eastern Journal of Research in Education, 2(1), 1-11.

Rashtchi, M., \& Mohammadi, M. A. (2017). Teaching lexical bundles to improve academic writing via tasks: Does the type of input matter? Electronic Journal of Foreign Language Teaching, 14(2), 201-219.

Rosenblatt, L. (1938). Literature as exploration. New York: D. Appleton-Century.

Rosenblatt, L. (1976). Literature as exploration. New York: The Modern Language Association of America.

Rosenblatt, L. (1985). The transactional theory of the literary work: Implications for research. In C. R. Cooper (Ed.), Researching response to literature and the teaching of literature (pp. 33-53). Norwood: Ablex.

Shafer, G. (2013). The problem of literature in composition classes. Language Arts Journal of Michigan, 28(2), 34-40.

Sherman, K. (2013). How social media changes our thinking and learning. The Language Teacher Online. https://jaltpublications.org/files/pdf-article/37.4tlt_plenary3.pdfJALT Accessed 12 Dec 2018.

Smagorinsky, P. (2002). Teaching English through principled practice. Upper Saddle River: Pearson.

Spack, R. (1985). Literature, reading, writing, and ESL: Bridging the gap. TESOL Quarterly, 19(4), 703-725.

Sumara, D. J. (1995). Response to reading as a focal practice. English Quarterly, 28(1), 18-26.

TOEFL Test Preparation Kit. (1995). Princeton. NJ: Educational Testing Service.

Topping, K. (2001). Thinking reading writing. London: Continuum.

Wegerif, R. (2006). Literature review in thinking skills, technology and learning. https://www.nfer.ac.uk/media/1838/futl75.pdf. Accessed 20 June 2017

\section{Publisher's Note}

Springer Nature remains neutral with regard to jurisdictional claims in published maps and institutional affiliations.

\section{Submit your manuscript to a SpringerOpen ${ }^{\circ}$ journal and benefit from:}

- Convenient online submission

- Rigorous peer review

- Open access: articles freely available online

- High visibility within the field

- Retaining the copyright to your article

Submit your next manuscript at $\boldsymbol{\nabla}$ springeropen.com 